\title{
FEMORAL NERVE BLOCK FOR FRACTURED SHAFT OF FEMUR
}

\author{
Antappa Shantappa Tondare and Arvind Vithalrao NadKarni
}

\section{ABstract}

Twenty five adults and children with fractured shaft of femur were given femoral nerve block for pain relief. The block was found to be useful for purposes of transportation and immobilization. The pain relief was complete if the fracture site was in the middle third of the femoral shaft. The block is easy, safe, economical and most useful in emergency and poor risk patients.

KEy WORDS: ANAESThetic TEChNiques, Regional, femoral nerve block; Fracture, Shaft of femur.

Femoral nerve block for fractured shaft of femur has not received its due consideration, although the block provides quickest and most effective pain relief. ${ }^{1}$

Patients with fractured shaft of femur present at the hospital in severe pain which arises from the periosteum, which is one of the very sensitive structures in the body. Little detail is available concerning the nerve supply of the periosteum covering the shaft of the femur. Last ${ }^{2}$ refers in general to the periosteum of superficial bones deriving its supply from the nerves to the overlying skin, while in deeper parts the motor branches to nearby muscles provide the supply. It seems likely that the nerve supply to the periosteum of the femoral shaft is derived principally from the femoral nerve supplying the quadriceps femoris muscle, which has major attachments to the shaft of the bone. Pain causes spasm of the thigh muscles, leading to displacement of the broken bone ends and so to a vicious circle of more pain and consequent spasm. This produces a state of neurogenic shock which might aggravate any oligaemic shock from occult blood loss into the thigh at the fracture site.

We studied the effectiveness of femoral nerve block in 25 patients with fractured shaft of femur admitted to our hospital, of whom 17 were male and 8 female. Their ages ranged from 5 to 35 years. The majority of the patients (17) were

Antappa Shantappa Tondare, M.D., D.A., M.B.B.S., Lecturer in Anaesthesiology; Arvind Vithalrao Nadkarni, M.D., D.A., M.B.B.S., Reader in Anaesthesiology; Medical College \& Hospital, Aurangabad, Pin Code: 431 001. Maharashtra State (India).

Can. Anaesth. Soc. J., vol. 29, no. 3, May 1982 emergencies who were unprepared or ill-prepared, and a few had associated injuries. Only eight were in-patients. No analegesic supplement was given to assure more accurate evaluation of the pain relief from the block alone. Blocks were carried out by Labat's technique as decribed by Moore, ${ }^{3}$ using lidocaine hydrochloride one per cent with adrenaline $1: 180,000(\mathrm{~W} / \mathrm{V})$. Ten $\mathrm{ml}$ was used in adults. In children the amount was limited to $5 \mathrm{ml}$. Lidocaine was preferred over other local anaesthetics because of quick onset of action and the greater success rate due to its high tissue penetrating power. Intensity of pain was assessed both subjectively and objectively, on movement of fracture site, rotation of and traction on the injured limb, before and after giving the nerve block.

Seven nerve blocks were done for transportation of patients from the emergency surgical ward to the radiology department, eight for immobilization by splint with skin traction, and ten for reduction and application of a hip spica. The block was found to be most useful in almost all patients for transportation and immobilization by splint with traction. Results were considered fair for reduction and hip spica application, in that a few patients needed supplementation with nitrous oxide and oxygen or intravenous pethidine because they complained of perineal and positional discomfort while on the spica table.

Pain relief is complete and best results are obtained if the fracture involves the middle third of the femoral shaft. Out of the 18 patients with the site of fracture in the middle third of the shaft, only one patient who had a hip spica 
TABLE I

THE INCIDENCE OF SUPPLEMENTATION IN RELATION TO FRACTURE SITE

\begin{tabular}{|c|c|c|c|}
\hline \multirow[b]{2}{*}{ Fracture site } & \multirow{2}{*}{$\begin{array}{l}\text { Number } \\
\text { patients }\end{array}$} & \multicolumn{2}{|c|}{ Supplementation } \\
\hline & & Number & Per cent \\
\hline Upper third & 4 & 3 & 75.0 \\
\hline Middle third & 18 & 1 & 6.0 \\
\hline Lower third & 3 & 1 & 33.3 \\
\hline
\end{tabular}

applied needed supplementation to complement the regional analgesia. In fractures of the lower third of the femoral shaft analgesia was not complete, but appreciable pain relief was still obtained, particularly when the fracture was relatively proximal in site. Satisfactory analgesia was difficult to obtain when the fracture site was in the proximal one third and almost always required some form of analgesic supplement. The incidence of supplementation in the three groups is shown in Table $I$.

In seven adults, in whom the effect of the first nerve block had worn off after 2 to $2 \frac{1}{2}$ hours, the block was repeated at the patients' own request, this time with bupivacaine hydrochloride 0.25 per cent, $10 \mathrm{ml}$. The nerve blocks were most appreciated and gratifying in children, as they made them less apprehensive and less hostile.

Since in clinical practice fractures of the middle third of the shaft of the femur are most common, the use of femoral nerve blocks in these cases is likely to be rewarding. As the quadriceps femoris gets its motor supply through the femoral nerve the block leads to relief of spasm, assisting further in the reduction and immobilization of the fracture. However, to have complete pain relief when the fracture site is either at the proximal or distal one third of the shaft is difficult due to the additional innervation in these areas by the obturator and sciatic nerves.

The technique of the block is easy and requires no special expertise. It can be learned and practised in the casualty department. No special equipment is necessary, except for a syringe and needles, and the block can be completed within a couple of minutes. Besides the technical considerations, it is logical that, as the femoral nerve block is safer and more effective with less physiological trepass than the use of narcoticanalgesic drugs, it is especially indicated in emergency and bad risk cases.

\section{ACKNOWLEDGEMENT}

We wish to express our gratitude to Dr. V.B. Dave, Professor of Anaesthesiology and Dr. S.G. Gurjar, Professor of Orthopaedics, for their guidance and encouragement throughout this study.

We are also grateful to Dr. V.R. Deshpande, Dean, Medical College and Hospital, Aurangabad for his kind permission to carry out and to publish this work.

\section{REFERENCES}

1. BERRY, F.R. Analgesia in Patients with fractured shaft femur, Anaesthesia, 32: 576 (1977).

2. LAST, R.J. Anatomy Regional and Applied, 5th ed. London, Churchill (1972)

3. Moore, D.C. Regional Block, 4th ed. Springfield, Charles C. Thomas (1971).

RÉSuME

Un blocage du nerf fémoral a été effectué chez vingt-cinq patients (adultes et enfants) présentant une fracture de la diaphyse fémorale. Ce bloc s'est avéré très utile à la fois pour le transport du patient et pour l'immobilisation de la fracture. La douleur était complètement soulagée dans les cas de fracture du tiers moyen du fémur. Il s'agit d'une technique facile, sécuritaire, peu coûteuse et particulièrement utile dans les cas d'urgence et chez les mauvais risques. 